\title{
Wrath: A Brief Reader Review
}

\section{Wight Martindale, Jr.}

Peter Wood has written another brilliant book, Wrath: America Enraged (2021), but perhaps he should have selected a different title. Yes, the book is about Wrath, a great sin, but it is also about Patience, a great virtue, and that is the title I prefer.

I assume most $A Q$ readers are familiar with John Milton's Paradise Lost. That epic poem is, in large part, about wrath, the wrath of Satan, who is eternally evil because he is eternally angry. He's angry with God and the world he has given us. He lives in hell, where he properly belongs. Forever.

George Washington, Peter Wood reminds us, was capable of great patience, although as an intensely righteous man, he was plenty mad quite often. Washington's patience contributed to his greatness and his regular successes in the most difficult of professions-politics and war.

Lincoln, too, was capable of patience, sometimes to a fault, as in his tolerance of poor generals. But Lincoln finally got it right in his choice of Ulysses Grant, a general who was not particularly angry, completely apolitical, and who didn't “scare worth a damn.” He was also a winner. William Sherman, an equally able general, was an angrier man, and thus, useful at times. But he was not the leader that Grant was.

Joseph Epstein has written an important little book, Charm, which I hope is still selling well. In it he explains how two great jazz musicians, totally unlike one another in every way, became huge successes. Blacks were still living with Jim Crow in their day, but Louis Armstrong and Duke Ellington rose above it. They did not turn their backs on their audience; they smiled, they played on, and audiences loved them. They exuded charm. Like Lincoln and Washington, they have become immortal.

\footnotetext{
Wight Martindale, Jr. taught honors seminars at Lehigh University for twelve years and was an adjunct professor in the Honors Program at Villanova University; wight.martindale@gmail.com. A former vice president at Lehman Brothers, he is the author of Inside the Cage: A Season at West 4th Street's Legendary Tournament (Simon and Schuster, 2005) and Don Quixote Goes to College: From the Trading Floor to the Classroom, A Memoir on Education (privately printed, 2013). He last appeared in these pages with "The New Gilded Age: We've Seen It All Before" (Fall, 2021).
} 
When the dreaming Don Quixote descends into the Cave of Montesinos to meet with the sage Durandarte (Part II, Chapter 23) what is he told? What priceless piece of wisdom is forthcoming? "Patience, and shuffle (the cards)." That is, we must play the hands we are dealt in life, and do the best we can.

Daniel Henninger of the Wall Street Journal thinks today's political rage began with the victory of George Bush over Al Gore in 2000, but Wood is far more comprehensive. Malcolm X, we are reminded, discovered the charismatic power of rage in the 1960s, only to be assassinated in 1965, when he showed signs of mellowing.

It is also hard not to be disturbed by Wood's section on “Teaching Anger," which is about the current craze for teaching women-even school girls-to embrace rage, confrontation, and resentment. Books like Rage Becomes Her (2018) can’t be helpful. Aren’t women usually the peacekeepers in the family?

This too, is an old story.

In Henry James's 1886 novel, The Bostonians, we are introduced to Olive Chancellor, a Boston bluestocking reformer described by her more conventional sister as a champion of prohibition, women's rights, mesmerism, various spiritualisms -in short, "a female Jacobin, a nihilist. Whatever is, is wrong. . . . She would reform the solar system if she could get hold of it."

Peter Wood's book must have been extremely difficult to write, cataloging one bad person and one bad idea after another. Rage is not a virtue, and it should never be confused with strength-Milton made this clear. Wood summarizes our situation today: “As Americans grew angrier they also grew more divorced, more socially isolated, and more miserable.” Wrath is almost always associated with power, a very dangerous idol. It is self-destructive and divisive.

All this at a time when Americans are richer than ever, and basic comforts and conveniences have been extended to more people than ever before. Perhaps we should reconsider Aristotle, who reminded us that man's greatest desire is, or should be, happiness. We owe it to ourselves to be happy, and we should act happily even when we are not particularly happy.

As Wood concludes, righteousness is a good thing, "but righteous indignation isn't a diet on which most of us chose to live.”

Enough already! 